\section{Locke, natural law and civil peace: Reply to Tate}

\author{
Paul Bou-Habib \\ University of Essex, Colchester, UK
}

European Journal of Political Theory $0(0)$ I-7

(C) The Author(s) 2016 Reprints and permissions: sagepub.co.uk/journalsPermissions.nav DOI: 10.1 I77/I474885 I |6650422 ept.sagepub.com

@SAGE

\begin{abstract}
In this comment, I reply to two objections John Tate raises against my discussion of the trajectory of Locke's ideas on toleration (in an earlier article published in EJPT, 'Locke's Tracts and the Anarchy of the Religious Conscience') Tate maintains that I misunderstand the role of natural law and civil peace in Locke's thought. I defend my interpretation of the role of natural law and show that Tate is mistaken in his claim that Locke's concern to preserve civil peace conflicted with his separate concern to protect individual rights.
\end{abstract}

\title{
Keywords
}

Locke, natural law, civil peace, toleration, rights

In his earliest political writings, the Two Tracts on Government (1660-62), Locke held that the right to religious toleration did not protect anything other than the freedom of inward religious judgment. In An Essay on Toleration (1667), by contrast, he embraces the view that religious toleration should extend to liberty of action in worship. Divine worship, he say, deserves 'an absolute and universal right to toleration'- (1667: 136)

What explains Locke's change of mind regarding the extent of religious toleration? In Bou-Habib (2015) I argued that there are two parts to that answer. First, Locke's understanding of the scope of political authority evolves from one text to the other. The Tracts evince a Hobbesian understanding of political authority according to which 'the object and matter of legislative power ... [is] all indifferent things'- (1660-62: 71, my italics). By 'indifferent things' Locke means all actions that God has not already regulated. The Essay limits the scope of political authority as follows: 'What was the end of erecting government ought alone to be the measure of its proceeding' (1667: 135, my italics). As Locke repeatedly emphasises in the Essay, people establish government only to protect themselves against harm, and given that the religious worship of others is (in its ordinary instances) harmless,

\section{Corresponding author:}

Paul Bou-Habib, University of Essex, Colchester CO4 3SQ, UK.

Email: pbou@essex.ac.uk 
the ends of government do not justify the regulation of indifferent action in worship.

Secondly, Locke alters his view concerning the status of indifferent action in worship. Consider the most striking passage of the Essay:

[I]n religious worship nothing is indifferent, for it being the using of those habits, gestures, etc. and no other, which I think acceptable to God in my worshipping of him, however they may be in their own nature perfectly indifferent, yet when I am worshipping my God in a way I think he has prescribed and will approve of, I cannot alter, omit, or add any circumstance in that I think the true way of worship. (1667: 139)

Whereas in the Tracts, Locke had said: 'indifferent things, even those regarding divine worship, must be subjected to governmental power' (1660-62: 69), in the above passage he says, by stark contrast, that the duty of sincerity transforms the status of an otherwise indifferent action, so that it now falls outside of the government's jurisdiction.

Both of these developments in Locke's thinking have their source in reflections on natural law that he undertook in his Essays on the Law of Nature (1663). I think Locke saw in natural law the promise of a kind of 'public reason' that would limit the extent to which people would quarrel about the ends of government, and began veering away from the Hobbesian injunction he had endorsed in the Tracts, that sovereign authority must be fixed simply over all indifferent things. I also believe Locke's natural law reflections made him more confident in the following respect: he came to believe that people who worshipped sincerely would reason themselves to, and comply with, their most basic natural duties, and that they could therefore be tolerated in their actions in worship.

\section{The significance of natural law}

Tate raises two main objections to the above account of Locke's developing views on toleration. His first objection is that I misunderstand the significance of natural law in Locke's political thought. There are two points he makes in this connection. The first is about chronology. Locke mentions natural law in the Tracts, so Tate asks the following question: 'If Locke saw natural law as consistent with his antitoleration position in the Two Tracts, on what basis does it suddenly perform the opposite service in the wake of this text and manage his transition to toleration?' $(\mathrm{XXXX})$, [AQ1]

The fact that Locke mentions natural law on several occasions in the Tracts doesn't imply that his thoughts about natural law couldn't have evolved in ways that were significant for his views on toleration. This is especially so given the very vague understanding of natural law displayed in the Tracts: in these texts, Locke shows no detailed grasp of the content of natural law or how we come to know it. He says quite simply that natural law requires order, and that order, in turn, requires that sovereign authority must stretch over all indifferent things. In the 
Essays on the Law of Nature, he develops a much more detailed understanding of natural law. He argues that we come to know it through reflections on our sense experience and he identifies three main categories of natural duty: (1) to worship god, (2) to preserve oneself and (3) to preserve society. ${ }^{1}$

Locke's description of the natural duty of worship is particularly noteworthy. He writes of man that

When he in himself finds sense-experience and reason, he feels himself disposed and ready to contemplate God's works ... and thereupon to assign and render praise, honour, and glory most worthy of so great and so beneficent a creator. (1663: 105-106)

The above passage suggests a further reason, in addition to the one I had put forward in Bou-Habib (2015), for why Locke's reflections on natural law might have led him to argue that action in sincere worship must be tolerated. The Tracts were mainly concerned with rejecting a particular argument Edward Bagshaw had made in favour of toleration, which appealed to a general liberty of conscience. Locke believed that if, as Bagshaw suggested, each individual must have a right to follow his conscience, there could be no political authority. I think Locke's reflections on natural law helped him to see that there is a different case for why actions in worship must be tolerated - different, that is, from the anarchical, consciencebased case Bagshaw made, and this is, simply, that religious worship is a natural duty. This different basis for toleration does not have anarchical implications: to have a right to worship is a more narrow privilege than having a right to follow one's conscience. As Locke subsequently puts it in the Essay, '[r]eligious worship, ... being an action or commerce passing only between God and myself, had in its own nature no reference at all to my governor, or to my neighbour and so necessarily produces no action which disturbs the community'- (1667: 138)

The other point Tate makes in connection with my understanding of the role of natural law in Locke is more difficult to grasp. He says that I assume that Locke believes that natural law is a source of civil harmony, whereas, in fact, 'Locke, in his later political writings, came to see natural law as a source of conflict rather than "harmony", $(\mathrm{XXXX)}$ According to Tate, Locke came to believe that natural law 'is of no use in the practical management of political authority' $\left(X_{X X X}\right)$. He observes that Locke increasingly emphasizes the idea that contract sets the scope of political authority: 'Unlike natural law ... which is present in the Two Tracts, "contract" (and its corollary of individual consent) is a new normative source that Locke affirms in the wake of the Two Tracts'-(XXXX). It is this idea, Tate thinks, that explains Locke's eventual endorsement of toleration.

Let me make two points in response. The first is that Tate misunderstands Locke's views on natural law. It is indeed central to Locke's thought that people will disagree about the content of natural law and about how to apply it in particular cases. That is why people must enter into political society with each other so that 'all private judgment of every particular member being excluded, the community comes to be umpire' (1689: §87). But it doesn't follow from this that Locke thinks natural law is of no use in the practical management of political authority. 
Locke states quite clearly that the 'Law of Nature stands as an Eternal Rule to all men, Legislators as well as others. The Rules that they make for other Mens Actions, must, ... be conformable to the Law of Nature' (1689: \$135). ${ }^{2}$ To say, as Tate does, that disagreement about natural law makes it of no use in the practical management of political authority is a bit like saying that moral disagreement makes morality useless in politics.

Furthermore, Tate contrasts contract and natural law as alternative sources of political authority, whereas, in fact, they combine as one source in Locke's thought. They do this, first, in determining who should have authority over whom: natural law asserts that we are all by nature equal, in the sense that no one is subordinate to another in jurisdiction over his own affairs (1689: §4), and this is why Locke believes that that no one can come to have authority over another other than by contract. ${ }^{3}$ Natural law and contract combine also to set the scope of political authority because political authority- 'being but the joint power of every member of the society given up to that person or assembly, which is legislator, it can be no more than those persons had in a state of nature', (\$135) which is, of course, the (jurisdictional) power that natural law had given them. And, furthermore, because natural law sets limits to the power each person has over himself (it forbids him destroying himself), it also explains why political authority cannot be absolute: "no body can transfer to another more power than he has in himself; and no body has absolute power over himself'. (\$135)

Secondly, it is not clear to me why Tate thinks I attribute to Locke the view that people are going to agree about the content and application of natural law. Perhaps Tate thinks that that view necessarily goes along with my claim that natural law sets the scope of political authority. But that isn't correct. One can acknowledge that individuals will disagree about the content and application of natural law, compatibly with believing that natural law sets the scope of political authority. One can hold that because individuals disagree about natural law, they must agree to obey the will of their representatives in a legislature, while also holding that those legislators must constrain their legislation in ways that enable individuals to fulfill the natural duties they would consent that government enable them to fulfill, and enjoy the natural rights they would consent that government protect.

\section{Civil peace}

Tate's second objection is directed at my interpretation of the role of civil peace in Locke's political thought. In my view, Locke does not make the right of religious freedom depend on what the consequences of respecting it would be for civil peace. This would imply that he would, for example, advocate withholding toleration for religious minorities when more powerful groups, who oppose their being tolerated, threaten violence, and this I said would amount to an unjust concession to the powerful at the expense of the powerless. I concluded that the civil peace interpretation of Locke's position on toleration wasn't compatible with his statements about the rights that individual dissenters have to being tolerated. So far as I can tell, Tate agrees with this, but rather than inferring, as I do, that Locke could not 
have endorsed the civil peace-based case for toleration, he concludes that Locke's political thought rested on imperatives that were at odds with each other.

Two points help to clarify the disagreement between Tate and me over the role of civil peace in Locke's political thought. First, we should distinguish between two versions of the civil peace interpretation. On an extreme version of it, Locke bases his early rejection and later endorsement of toleration solely on the consequences for civil peace. On the moderate version, he takes the consequences for civil peace into account, alongside the interests individuals have in being free from religious persecution. Tate clearly endorses the moderate version: he says that Locke comes to support toleration not only because of a concern for civil peace, but also because of a widening commitment to individual liberty. ${ }^{4}$ I was concerned to reject the extreme version (though I should have made this clearer). ${ }^{5}$ I was mainly concerned to show that Locke defends toleration because he cares about the interests that persons have in being able to worship sincerely.

Secondly, and having said this, Tate and I do disagree about exactly how civil peace is relevant for Locke. Tate sees Locke's concern for civil peace as being in conflict with the rights of individuals. The implication of this reading is that Locke is prepared to put up with injustice for the sake of peace. In support of this reading, Tate draws attention to Locke's discussion of the right of resistance to government. Locke argues that recognizing a right of resistance is compatible with maintaining civil peace because the larger part of the community will never be disposed to take up arms against government in support of a few individuals until 'the ill designs of the rulers become visible, or their attempts sensible to the greater part' (1689: §230). Tate explains Locke's reasoning as follows:

He [Locke] declares... that individual religious dissidents who engage in such resistance, no matter how valid their cause, are "busie heads" and "turbulent spirits", subject to "just ruine and perdition"... Locke is engaging in precisely that "unjust concession...to the prejudices of the powerful at the expense of the rights of the powerless" of which Bou-Habib thought him incapable. (XXXX),

In fact, it is far from evident, in my view, that Locke is engaging in an unjust concession to the prejudices of the powerful in his discussion of the right of resistance. Note two points about that discussion: first, the kind of 'resistance' Locke is talking about is not self-defense, but the endeavour to alter government by force. Secondly, Locke does not say that individuals are subject to just ruin no matter how valid their cause. That is Tate's phrase. What Locke does say is that a disruption of civil peace will not occur 'whenever it shall please a busie head, or turbulent spirit, to desire the alteration of government'- (1689: \$230)

These two points help to reduce the appearance of injustice in Locke's argument and allows us to see a more reasonable attitude behind it. He is assuming that if individuals impose the grave risk on others (and themselves) of seeking to alter government by force when the injustices they believe they suffer are not general but confined to a few instances, then they are subject to just ruin when the rest of the community don't back them up. That, to me, is not an unjust concession to the 
powerful at the expense of the powerless. It is not unjust to argue that people should refrain from using force against governments that are broadly legitimate. (It would be a different matter, of course, if a government perpetrated, or was intent on perpetrating, widespread abuses.) Tate's view that there is a serious conflict between civil peace and individual rights in Locke's political thought therefore appears unwarranted.

\section{Declaration of conflicting interests}

The author(s) declared no potential conflicts of interest with respect to the research, authorship, and/or publication of this article.

\section{Funding}

The author(s) received no financial support for the research, authorship, and/or publication of this article.

\section{Notes}

1. See Locke (1663: 106). As Wolfgang Von Leyden points out, in identifying these three categories of natural duty, Locke rehearses the main precepts of natural law according to Thomas Aquinas in Summa Theologiae, q. 94, art. 2. See Von Leyden's edition of Locke's Essays on the Law of Nature (1663 [1988]), p. 159.

2. Jeremy Waldron provides a good statement of how Locke saw the relationship between the law of nature and positive legislation: ' $F_{0}$ the extent that members of the society disagree about this [i.e. the law of nature] - to the extent that natural law is controversial legislation just is the adjudication of those controversies' (1999: 86).

3. I think Tate is misled into assuming that Locke contrasts contract and natural law because Locke contrasts contract with the idea that monarchy is 'jure divino' (1667: 135). The latter idea has nothing to do with natural law - it is the different idea that God has directly assigned political authority to the monarch.

4. But note that Tate's claim that Locke moves towards a more toleration-friendly position because of a widening commitment to liberty doesn't really explain that development in Locke's thought: it just describes it. We know that Locke comes to acquire a wider commitment to individual liberty: the question is why.

5. I wanted to reject the view that Locke 'defends the right to toleration in An Essay on Toleration... only because he now believes it is toleration, rather than imposition, that is most conducive to civil peace' (Bou-Habib 2015: 13).

\section{References}

Bou-Habib P (2015) Locke's tracts and the anarchy of the religious conscience. European Journal of Political Theory 14(1): I] [AQ2]. pp. 3-18.

Harris I (1994) The Mind of John Locke. [AQ3]Cambridge: Cambridge University Press. Locke J (1660-62 [1997]) First tract on government and second tract on government. In: Mark G (ed.) Locke: Political Essays. Cambridge: Cambridge University Press, pp.3-78.

Locke J (1663 [1997]) Essays on the law of nature. In: Mark G (ed.) Locke: Political Essays. Cambridge: Cambridge University Press, pp.79-133.

Locke J (1663 [1988]) In: von Leyden Wolfgan (ed.) Essays on the Law of Nane I[AQ4]Oxford: Oxord University Press, p. TI 
Locke J (1667 [1997]) An essay on toleration. In: Mark G (ed.) Locke: Political Essays. Cambridge: Cambridge University Press, pp.134-159.

Locke J (1689 [1963a]) Two Treatises of Government. In: (Peter Lasletted) New York, NY: New American Library, pp. [AQ5].

Waldron J (1999) The Dignity of Legislation. Cambridge: Cambridge University Press. 